UDK 338.24:614.4

Professional paper

\title{
TEMPORARY REGULATION OF COMPETITION AND CORONAVIRUS
}

\author{
Darija Vodanović, mag.iur., Production manager \\ AMM d.o.o. Vinkovci \\ Dr. Franje Rackog 10, 32270 Županja, Croatia \\ darija.vodanovic1@gmail.com
}

\begin{abstract}
Competition law as one of the foundations of a market economy whose main purpose is to ensure an equal position of entrepreneurs in the market, regardless of the size, market power and other features of the implied system of state aid both at central and local and regional level. The aim and purpose of this research is a clear and tentative way of pointing out the importance of competition in relation to coronavirus. In order to achieve this goal, the paper seeks to provide scientifically based answers to a number of current issues, starting from detention from the definitions of competition and coronavirus. In addition to the above, it is necessary to consider how this disease affected entrepreneurship, which had positive and negative consequences. In addition, it is important to note that it has left a significant impact on our mental health. The main results of the research point to the fact that the coronavirus as a global, economic and health crisis suddenly caught us all overnight and as such changed our lives. In addition to greatly affecting the economy, there is also a blow to the company. In case of suspicion of infection, the obligation to call a doctor, ie a territorially competent epidemiologist, and the obligation to go to an outpatient clinic are determined as a preventive measure. In this paper, qualitative research in correlation with quantitative research was used. Starting from the fact that quantitative research is based on the description of individual conditions, ie the establishment of cause-and-effect relationships, the paper in a representative way seeks to simplify the concept of competition as the driving force of a market economy that entails many benefits consumer choice, innovation. In addition, considering the coronavirus from a quantitative point of view, it is manifested in how the coronavirus as a new strain of virus, discovered in humans, 'stirred' the whole world as such forced people to care about their health and the health of our loved ones. Also, an obligation to adhere to epidemiological measures to prevent the spread of coronavirus infection has been introduced. Qualitative research, as a term used to describe research that focuses on the way individuals and groups view and understand the world, also has a significant impact on this work, primarily because it considers how the pandemic affected the health of people interacting with each other.
\end{abstract}

Keywords: Competition law, coronavirus, disease, quantitative research, qualitative research, pandemic 


\section{INTRODUCTION}

The aim of competition law as a primary feature of the economic structure in which the redistribution of resources is based on supply and demand in the market is to ensure the efficient operation or functioning of the internal market, and consequently other objectives. ${ }^{1}$ In the context of competition, it is important to establish a relationship between national law and EU competition, depending on whether a follow-up procedure is initiated after a public body has established the existence of an infringement or an independent procedure, if any. ${ }^{2}$ In modern competition, it is necessary to look at the concept of entrepreneur, which is defined as any entity involved in economic activity, regardless of its legal status or method of financing. In order to more efficiently and systematically ensure the right to compete in the market, it is necessary to create such conditions that will ensure free competition for entrepreneurs. On the other hand, in order to protect the interests of consumers, it is necessary to establish a ban on communication, which would artificially change the conditions on the labor market. Therefore, it is necessary to create conditions in which entrepreneurs will be guaranteed freedom of competition. Due to the coronavirus, many companies were hit, and their business was significantly endangered and thus their survival was called into question. Today we are facing one of the greatest epidemics in human history called the coronavirus. For a clearer understanding of the above, there will be more words in the coronavirus below as an important indicator of the impact on human health and normal functioning. The coronavirus, under the official name SARS-CoV-2, causes the infectious disease COVID-19 and from December 2019 to May 2020 conquered the whole world. In Wuhan, the capital of the Chinese province of Hubei, the virus was transmitted from an unknown reservoir to humans in December 2019, after which further classical human-to-human spread continued when animals in the infection transmission chain were no longer needed; referred to in epidemiology as the "spillover." Since we have pointed out that coronaviruses (but also many other viruses) are found in different animals, Chinese markets can also be considered incubators of infections that can be passed from many animals to humans. At first, it was not clear whether the virus could be transmitted from one person to another, or whether all infected people became infected from a common, same source. When the health care workers who cared for the infected people also became ill, the human-to-human transmission quickly became clear. From China, the disease has spread to many countries, and Europe currently has the highest number of cases in Italy. The first case in Croatia was described on February 25, 2020, and by the second half of April, almost two thousand infected

Kunda, Ivana, Law relevant for violations of competition law, Proceedings of the Faculty of Law, University of Rijeka, Vol. 39, No. 1., 2018, p. 183.

Ibid., p. 206. 
citizens had been recorded. In mid-April, there were about two million confirmed cases of infection globally, with about 160,000 fatalities. The spread of the disease took place on a global scale, so its spread began in China, after which it spread to Europe and then to America. The United States is considered the most affected country. It is evident that the virus is spreading very fast in populous countries that lag far behind in the application of relevant measures such as measures of social distancing, testing and isolation of infected persons and their contacts. In order to prevent the spread of the disease of the same name, many countries were forced to take various measures to protect the health of the population. Thus, one of the measures referred to the closure of borders and various strict epidemiological measures. The most important measures were the ban on movement, gatherings, work from home, the closure of kindergartens, schools, colleges, public parks, schools, service activities, and city and intercity traffic.

\section{COVID 19 AND ENTREPRENEURS}

The COVID 19 pandemic affects all aspects of our lives, starting with how we live, how we eat, what we do, how we spend money and what our basic life priorities are. In addition, it is necessary to consider how it affected entrepreneurship, what positive consequences it left on the same and what negative consequences it left on the same. A large number of SMEs have experienced a drop in demand with their products and services. Precisely because of this, it is not surprising that a number of drastic measures were needed, such as changes in the budget, changes in the dismissal of workers and the allocation of resources. An important fact is that in the last two months, 20,000 people have lost their lives. In addition to causing great change one should not lose faith, and one should believe that every change is a new opportunity. Here are some guidelines that entrepreneurs should follow if they want to continue their business successfully. It is first necessary to get acquainted with the specific situation and consider all aspects of the further development of the disease and its impact on entrepreneurship. It should then consider what changes a possible crisis will bring and which products and services will benefit consumers. Many customer changes will require new products and services, and they need to be analyzed in detail and find the ones that can be most useful to them. It is possible that some new market leaders in such situations will rise while others lag behind. "Who would be worse now is down" - this is where the door opens for new market competitors. Namely, it is necessary to be ready for new changes and quick adjustment of new strategies. One of the key elements to success is to quickly adapt to the changes and needs of its customers in a market that has undergone drastic changes. In this situation, it is not the time to relax and it is necessary to gain insight into the needs of its customers, primarily by talking to them, colleagues, employees. In the end, though, 
we're all in this together. One of the important instructions to entrepreneurs regarding working from home is that if working from home has proved successful, it is necessary to consider allowing them to work from home in the future. If not every day, then at least a few days a week. What is necessary is to arm yourself with optimism and keep the entrepreneurial spirit. The most important thing now is to arm yourself with good will and adapt to the 'new normal'. In doing so, it is necessary to remain true to its values and transparent to its customers. Since we now have more time, why not use it to better plan, rethink our goals and strategies, and set new goals that can be achieved to better avoid a crisis. We need to believe that this will end and that we will all be able to return to a relatively normal life after that. ${ }^{3}$

\section{HEALTH EFFECTS OF CORONAVIRUS}

The new strain of coronavirus has attracted a lot of attention, starting with how it originated, how it spread, how it affected the labor market and most importantly how it affected human health. Some people, especially the elderly and those who are already ill in particular can be ill. It is therefore crucial that we all work together to prevent the spread of the virus. Here are some key tips to prevent the spread of the infection. The first piece of advice is to stay home if we feel sick and if we are told so. Also, it is required to maintain a kind of distance of at least a meter and a half and other people. It is necessary to practice good hand hygiene and avoid coughing and sneezing. One of the first neurological symptoms of coronavirus is the effect on the brain, ie the loss of smell and hearing. But as the pandemic progresses, researchers are increasingly learning about how the eponymous disease affects the brain. Recent research has given us clues that have shed light on why COVID 19 can be so serious for humans and why symptoms can last so long. How many times during the day do we even remember to breathe? And isn't that when we sigh, because it's hard for us for some emotional or mental reason? Breathing is an exceptional function of our body, it is a sign that we are alive, but it can also reveal a lot about how to live our own life. Like most movements in our lives, the breath is automatic and our thoughts and feelings are also related to breathing. Scientists believe that the COVID 19 virus is not a respiratory disease. Once it infects the brain, it can affect the lungs, heart and everything. The brain is a very sensitive organ. It's a CPU for everyone. It could be said that the brain is one of the areas where viruses like to hide. ${ }^{4}$

3 Plechinger, Ivana, COVID-19 and entrepreneurs - how to take advantage of a bad situation for positive change; Entrepreneurship and COVID-19, https://www.radionica.hr/covid-19-i-poduzetnici/, Accessed 28 June 2021

4 Šimić, Vladimira, The latest coronavirus: how does COVID-19 affect the brain? https://www.adiva.hr/ zdravlje/koronavirus/posljedice-koronavirusa-kako-covid-19-utjece-na-mozak/, Accessed 29 June 2021 


\section{LEGAL REGULATION OF CONCENTRATION OF ENTREPRENEURS WITH SPECIAL REFERENCE TO THE INFLUENCE OF CORONAVIRUS ON SELF-ENTREPRENEURS}

Regarding the legal regulation of coronavirus, it is important to highlight the Commission Communication, is the Fifth Amendment to the Temporary Framework for State Aid Measures to Support the Economy in the Current COVID-19 Pandemic and the Annex to the Commission Communication to Member States on the Application of Articles 107 and 108. Union on short-term export credit insurance. Accordingly, on 19 March 2020, the Commission adopted a Communication entitled "Temporary Framework for State Aid Measures to Support the Economy in the Current COVID-19 Pandemic". On 3 April 2020, it adopted the first amendment with the aim of providing support intended to accelerate the research, testing and production of products essential for combating the spread of disease. The second amendment was adopted on May 8, 2020, with the aim of increasing the availability of capital and liquidity of companies affected by the crisis. A third amendment was adopted on 29 June 2020 to provide additional support to micro, small and start-ups and to encourage private investment. In addition, the fourth amendment of 13 October 2020 was adopted in order to extend the temporary framework and provide support to cover part of the uncovered fixed costs of crisis-affected undertakings. The aim of the temporary framework is to ensure an appropriate balance between the positive effects of the support measures covered by entrepreneurs and all possible negative effects on competition and trade in the internal market. Targeted and proportionate control of state aid in the European Union ensures the effectiveness of national support measures in terms of aid to affected companies during the COVID-19 pandemic, while limiting unjustified distortions of the internal market, distorting its integrity and ensuring fair competition. In this way, it seeks to contribute to maintaining the continuity of economic activity during the COVID-19 pandemic and to provide a basis for economic recovery after the crisis, bearing in mind the importance of achieving a green and digital transition in line with Union legislation and objectives. ${ }^{5}$ In the development phase of global competitiveness and globalization, company concentrations are an integral and mandatory part of modern business practice as such. One of the main reasons why entrepreneurs implement concentrations is to strengthen competitiveness, expand into a new market or to preserve existing or current market positions. Concentrations of undertakings as such, as a

Commission Communication, Fifth Amendment to the Temporary Framework for State Aid Measures to Support the Economy in the Current COVID-19 Pandemic and Amendment to the Communication to the Commission Communication to Member States on the Application of Articles 107 and 108 of the Treaty on the Functioning of the European Union to Short-Term Export Credit Insurance, (2021) OJ C34/06 
rule, have the ultimate goal of strengthening competition and improving competition, since they contribute to the improvement of production and innovation, and thus, to the competitiveness of undertakings. Before the same analyzes and entering into the issue of concentration as such, it is necessary to first elaborate the legal framework, whereby the Law on Protection of Market Competition was first established.

\subsection{Competition Act}

The harmonized development of law and practice as such has built an effective system of legal rules that consistently seek to implement competition policy. The Law on Protection of Market Competition is a basic and regulatory act which regulates the matter of market competition as such. Furthermore, it regulates the organization, powers and tasks of the competition authority as well as the procedure related to its implementation. But its application is not limited to the above. Namely, the same applies to all forms of prevention, restriction or distortion of competition by entrepreneurs, both in the territory of the Republic and outside the territory of the Republic of Croatia, if they have an effect on the Republic of Croatia. Pursuant to Article 15 of the Law on Protection of Market Competition, concentrations as such arise through mergers and acquisitions, the acquisition of control or dominant influence of one undertaking over another and the creation of a joint venture acting on a more permanent basis as an independent entity. ${ }^{6}$ The term concentration is understood as various forms of connecting companies, both on a status and contractual basis. A common feature of concentrations as such is to create a legal or economic community between the parties to the concentration who were legally and economically independent undertakings prior to the implementation of the concentration. ${ }^{7}$

\subsection{Entrepreneur competition}

The basis and basis of concentration as well as the key to its emergence is the acquisition of control. Control is exercised by transferring rights, contracts, or other means by which one or more undertakings, either individually or jointly, acquire the possibility of exercising dominant influence over one or more undertakings or part of one or more undertakings on a more permanent basis. ${ }^{8}$ In today's business

Competition Act, (Zakon o zastiti trzisnog natjecanja), (Official Gazette, No. 79/09, 80/13, 41/21)

Akšamović, Dubravka, Legal Regime for Concentrations of Entrepreneurs in Competition Law, Collected Papers of the Faculty of Law, University of Rijeka, Vol. 29, No. 2., 2008, pp. 1034-1036

8 Momčinović, Hrvoje, Concentration, http://www.aztn.hr/trzisno-natjecanje/nadleznosti/koncentracije/ Accessed 29 June 2021 
conditions in which the increasingly demanding domestic and foreign markets prevail, it is important to emphasize the strengthening of the competitiveness of entrepreneurs as one of the factors that should not be neglected. In order to preserve market positions and strengthen competition in market competition, entrepreneurs are obliged to adhere to all legal institutes, taking into account that their connection is legitimate and permissible, especially from the point of view of competition regulations. In today's business conditions, it is important to emphasize the strengthening of the competitiveness of entrepreneurs as such in both domestic and foreign markets. In order to preserve market positions and preserve competitiveness in market competition, it is necessary to intensify competition in terms of lowering prices and ensuring better quality of goods and services. In the conditions of global competitiveness, where strengthening the competitiveness of entrepreneurs is the backbone of the economic policy of each country, the considered measures are a very important balance for establishing a balance between the implementation of competition policy and economic development policy. It is important to note that one of the possible goals of competition, when it comes to concentrations as such, is to provide innovative solutions, reduce production costs and improve production and other benefits for consumers and society as a whole.?

\subsection{Punishing the concentration of entrepreneurs}

Considering the concentration of undertakings, it is first necessary to examine whether in this particular case it is a concentration of undertakings. According to the Croatian competition law, when one undertaking acquires control over another, the notification of the intention to implement the concentration must be submitted by the one who acquires control. If the entrepreneur fails to file the application, and was obliged to do so, the sanction may amount to up to one percent of the value of the total annual income of the entrepreneur. If the prohibited concentration of undertakings is actually implemented, the undertakings participating in it may be fined up to ten percent of the total value of income. ${ }^{10}$

\section{IMPACT OF CORONAVIRUS ON THE LABOR MARKET}

The coronavirus pandemic has caused profound and lasting changes in the global labor market. At the same time, it is important to point out the collapse of certain sectors and the rise of new ones, as well as the increasingly widespread work from

Ibid., pp. 1059-1060

10 Zrno, Marija, , How to make money on panic due to coronavirus; Protection of competition: How to avoid penalties in case of concentration of undertakings, Lider - business weekly, Vol. 16., No. 752.,2020, pp. 49.-51. 
home. It is a delusion to think that everything will go back to normal. Unfortunately it won't, nothing will be the same as before. It is believed that we must have a vision of a new normal that will allow us to adapt to new circumstances. At least 90.5 million people worldwide have been infected with the coronavirus so far, while about 1.9 million people have died as a result of the infection. The pandemic has fundamentally changed companies and workers in almost every country in the world, in parallel with the introduction of strict blockades. It is important to point out that a huge loss of jobs has been observed and that it creates a fiscal gap that could further deepen inequality between richer and poorer countries. The International Labor Organization is watching and warning about the same. Workers were affected by the pandemic in a way that reshaped their working day, as millions were forced to work from home. Namely, many were satisfied that they no longer have to travel long distances by public transport, but their working hours are reduced to having to move from room to room. Namely, research has shown that the vast majority of workers would prefer a combination of working from home and working in the office in the future. Also, the need for a more flexible and innovative approach to education will not disappear with a pandemic. The question is: "How many children today will be doing jobs that don't currently exist? The answer is still unknown. ${ }^{11}$

\subsection{Preservation of jobs during coronavirus}

Measures to preserve jobs, ie regulations on the labor market, have generally been introduced in order to improve employment and job security through cash benefits or social security programs. What needs to be put at the center is to look at the extent to which jobs have been preserved in this current pandemic, ie how often business-related redundancies occur, whether and how they can be avoided, and what measures are needed to address this problem. . The fact is that no matter which part of the world or which sector is affected, the crisis has a dramatic and comprehensive impact on the world of work. Therefore, policy measures should focus on the immediate easing of the position of workers and employers in the labor market by providing livelihoods and economically viable operations, especially in activities hard hit by the pandemic and developing countries. Therefore, limited public resources should be used in a way that will encourage employers to retain existing and / or create new jobs. In the early stages of the COVID crisis 19, many governments modified existing job preservation schemes to introduce the above objectives and introduced new ones. limiting the application of main-

11 Barač, Ivana, Coronavirus is permanently changing the global labor market, https://privredni.hr/koronavirus-trajno-mijenja-globalno-trziste-rada, Accessed, 30 June 2021 
tenance subsidies to those jobs that would certainly be preserved or to those that are unprofitable in the long run. Employment policies and packages to support employers and protect workers from unemployment risks, but also to develop new employment opportunities have been implemented in many countries as an immediate response to the emerging pandemic. The most commonly used measures are: support schemes for job maintenance, wage support, initiatives for work-sharing and shortening of working hours, temporary suspension of tax payments 16 and social benefits, etc. ${ }^{12}$

\subsection{Measures of the Government of the Republic of Croatia for the preservation of jobs}

With the adoption of the Decision on declaring the epidemic of the COVID-1943 disease on March 11, 2020, numerous changes in employment relations and in the manner of performing work occurred for employers and workers. These are the following measures: support for shortening working hours; support for the preservation of jobs in the textile, clothing, footwear, leather and wood production sectors; support for the preservation of jobs in activities affected by coronavirus (COVID 19); support for the preservation of jobs in sheltered workshops, integrative workshops and work units. The Government of the Republic of Croatia authorized the Minister of Finance to sign the Voluntary Guarantee Agreement between the Republic of Croatia and the European Commission for temporary support to reduce the risk of unemployment in an emergency situation after the outbreak of COVID-19, ie approved entry into the SURE program. 59 Hereinafter, the two most commonly used measures will be presented: shortening of working hours and support for the preservation of jobs in activities affected by coronavirus (COVID 19). ${ }^{13}$ This measure is financed from the aforementioned SURE program. The support can be used by employers who perform economic activity and employ ten or more workers. The basic criterion as a condition for using the measure is the expected decline in the total monthly working hours of all employees employed by the employer on a full-time basis in the month for which support is required of at least $10 \%$. In addition, the employer must demonstrate a link between the impact of the COVID 19 epidemic on business and the expected decline in the total monthly working hours fund. Evidence of the connection between the Croatian Employment Service is a decrease in turnover of receipts in each month for which support is requested of at least $20 \%$ compared to the same month last year and one of the following reasons: a decrease in orders on the drop

\footnotetext{
12 Bilić, Andrijana, Mokrović, Domagoj, Preserving jobs during the covid pandemic crisis 19, Proceedings of the Faculty of Law in Split, Vol. 58, No. 2., 2021, pp. 535-536

$13 \quad$ Ibid., pp. 528.-529.
} 
in orders for the month for which support is requested; inability to contract new jobs during the epidemic; inability to deliver finished products or contracted and paid raw materials, raw materials, machinery, tools; impossibility of new orders of raw materials, raw materials, tools and machines necessary for work. It is granted for temporary only if there has been a reduction in the monthly fund of working hours by more than $70 \%$. The amount of the subsidy is a maximum of HRK 2,800 per month net per worker. ${ }^{14}$

\subsection{Shortening working hours}

Employers who perform economic activity and employ ten or more workers. The basic criteria as a condition for using the measure are the expected decline in the total monthly working hours of all workers employed by employers on a full-time basis in the month for which they seek support of at least $10 \%$. In addition, the employer must prove the connection between the impact of the COVID 19 epidemic on business and the expected decline in the total monthly working hours fund. The Croatian Employment Service considers proof of the connection a decrease in the turnover of receipts in each month for which it seeks support of at least $20 \%$ compared to the same month last year and one of the following reasons: decrease in orders orders for the month for which support is requested; inability to contract new jobs during the epidemic; inability to deliver finished products or contracted and paid raw materials, raw materials, machinery, tools; impossibility of new orders of raw materials, raw materials, tools and machines necessary for work. It is granted for temporary only if there has been a reduction in the monthly fund of working hours by more than $70 \%$. The amount of the subsidy is a maximum of HRK 2,800 per month net per worker. ${ }^{15}$

\subsection{Support for job preservation in activities affected by COVID-19}

This aid could be conditionally called a "fundamental" measure, given that it was the first of these measures to apply. Employers need to prove that in the period from 1 April to 30 September 2020 they had a decrease in income / receipts compared to the same period in 2019, unless they could not work due to Staff Decisions when comparing their income with September 2019, but in that case, they can use the support only for the month in which their work was disabled. ${ }^{16}$

\footnotetext{
$14 \quad$ Ibid., p. 537.

$15 \quad$ Ibid., p. 537.

16 Ibid., pp. 537.-538.
} 


\subsection{Abuse of aid to preserve jobs}

Shortly after the payment of the first aid for the preservation of jobs, there were also cases of their abuse by employers. Namely, there are a number of employers who do not pay the benefits they receive from the state to the workers at all, or pay them only partially, or reduce the salary only to the amount of the aid or part of the aid. would achieve personal gain to the detriment of their own workers. ${ }^{17}$

\section{OVERVIEW OF OTHER COUNTRIES'S ACCESSIONS TO MEASURES TO PRESERVE JOBS}

\subsection{Republic of Slovenia}

Similar to the Republic of Croatia, the Republic of Slovenia presented a legal package of measures for the purpose of financial assistance to workers on 2 April 2020 (with retroactive application from $13 \mathrm{March}$ ) and supplemented and amended it 4 more times by the time this paper is written. The initial package, depending on the intensity of termination of employment, provides for 3 options: 1 . to all workers who remained in their jobs, the state paid pension insurance benefits for April and May. 2. in case of temporary cessation of work (eg leave), the state undertook to pay salaries in the amount of $80 \%$ of the average salary of workers in the past 3 months to the average salary in the Republic of Slovenia in 2019 and social contributions, if the employer expects of $10 \%$ compared to 2019.3. Workers who lost their jobs during the pandemic and did not qualify for unemployment benefits received compensation in the amount of EUR 513.64 gross per month. The self-employed, agricultural workers and religious workers who expected a drop in income of at least $10 \%$ compared to 2019 , were entitled to a fixed monthly allowance of 350 euros for March and 700 euros for April and May, in addition to social security contributions for April. and May. Special attention was paid to workers who were forced to stay at home and take care of their children due to the closure of kindergartens and schools or the closure of public transport and borders - they were also provided with compensation in the amount of $80 \%$ of salary and social security contributions. The package of measures from May 29 extended the salary compensations in case of temporary termination of work, but also introduced measures for the introduction of part-time work programs. Namely, the state will subsidize up to 20 hours per week for employers who cannot provide at least $90 \%$ of the usual workload for a minimum of $10 \%$ of employees. It is in use until the end of 2020. The fifth package of September 23, in addition to extending the existing measures, has strengthened assistance to the self-employed and micro-

$17 \quad$ Ibid., p. 538. 
entrepreneurs by entitling them to a monthly amount of 1,100 euros by the end of the year if they have a revenue decline of at least $30 \%$ compared to 2019 . But the most interesting news comes with the introduction of a system that puts the amount of wage compensation to which a worker is entitled in relation to his behavior and travel during a pandemic. Thus, a worker who is in quarantine due to contact with an infected person within the workplace is entitled to compensation of $100 \%$ of the salary. A worker who is quarantined upon return from the country from the green or orange list due to the risk of infection at the time of departure is entitled to 80 percent compensation. A quarantined worker because he traveled to a redlisted country for justified reasons (death of a spouse or common-law partner, child or parent; birth of a child;) is entitled to $50 \%$ of the salary he would have received if he had worked, and at least $70 \%$ of the minimum wage; summons to court) with prior notice to the employer. Other workers who are quarantined for travel to red-listed countries for reasons other than those listed above are not eligible for any wage compensation. ${ }^{18}$

\subsection{Republic of Germany}

Germany has entered a partial economic lockdown in order to prevent the socalled. the second wave of the pandemic. Accordingly, the measures it proclaims are more of an economic nature - fees and one-off grants with the aim of helping companies in business, which only indirectly achieves the effect of preserving jobs. The government undertakes to compensate companies that employ less than 50 workers $75 \%$ of the income generated in November 2019, and those with more than 50 employees up to 67 working hours. Companies in which at least one tenth of workers (including temporary workers) have a decrease in the amount of work are entitled to benefits for the implementation of the program, and the state fully bears social security benefits (health insurance, pension insurance, etc.). The amount of compensation is $60 \%$ of the previous net salary, but in case the measure lasts, in the 4th month of implementation it increases to 70 or $80 \%$ from the 7 th month of implementation until the end of 2021. Access to unemployment benefits is facilitated and the period of their payment is extended, and support mechanisms are created for start-up companies and artists. In terms of taxes, the food tax in the hospitality industry will be reduced from 19 to $7 \%$ by June 30, 2021. Other tax breaks include a moratorium on tax debts and a suspension of sequestration. ${ }^{19}$

\footnotetext{
$18 \quad$ Ibid., p. 540

$19 \quad$ Ibid., pp. $540 .-541$
} 


\subsection{Republic of Austria}

In the Republic of Austria, even before the outbreak of the pandemic, the law governing action in the event of an epidemic was in force (Epidemiegesetz 1950). The outbreak of the COVID 19 pandemic complements its standards to make them applicable to the current situation, which includes the power of the state to declare the closure of certain activities to prevent the spread of infection. The powers under this Act go so far that, under certain conditions, inspections may also enter the homes of residents in order to perform testing and implement measures. This same law also prescribes the right of legal and natural persons to demand compensation from the state in the event of a drop in income caused by one of the prescribed reasons (quarantine; living and working in an area subject to traffic restrictions; working on jobs covered by restrictions or complete closure; managing such affairs). In addition to the above existing legislation, since the beginning of the current pandemic, the Republic of Austria, like Germany, has decided to indirectly protect jobs through economic measures to compensate companies with the implementation of part-time measures in accordance with SURE program EU-Program of part-time work in Austria. Kurzarbeit ", allows companies in all sectors to reduce working hours from 10 to $90 \%$ for a period of 6 months in the event of economic difficulties caused by a pandemic. Also, the application procedure for unemployment benefits has been facilitated and the amount of benefits granted to families of lower economic status or whose members have become unemployed has been increased. Unemployed people are also paid a one-time benefit in the amount of 450 euros. A salary subsidy in the form of a "new start-up bonus" is also planned, intended for employment and quick filling of vacancies, calculated from the difference between the net compensation for work done and about 80 percent of the net unemployment benefit, including social security contributions up to a maximum of 950 euros net. ${ }^{20}$

\subsection{Great Britain}

With the onset of the pandemic, the United Kingdom decided, on the one hand, to adopt a package of measures that did not exist until then, but also to adapt the already existing social security measures to the new situation. First of all, the statutory sick pay (SSP) has been changed in such a way that persons are entitled to it from the first day of absence from work due to illness, unlike the previous rule according to which they exercised their right only after the 4th day. . Also, a package of benefits for small and medium-sized enterprises is added to this system by reimbursing the employer for up to 2 weeks of paid compensation for a

$20 \quad$ Ibid., pp. 541.-542. 
worker who was absent from work due to COVID 19. To help the self-employed, a measure called Self-employment Income was adopted. Support Scheme which pays people up to 390 pounds per month for up to 3 months. The main measure to help workers has been adopted under the name Coronavirus Job Retention Scheme. It was brought at the beginning of the pandemic and extended several times. This measure currently covers $80 \%$ of a worker's salary for hours he has not worked (whereby the worker has had to be absent from work for a minimum of 7 consecutive days), up to $£ 2,500$ a month. to $£ 3,000$ monthly support. The United Kingdom has paid special attention to young people with minimal work experience, ie those who have yet to gain it, so it has adopted a measure called 552 long-term unemployment risk covering 100 percent of the national minimum wage for 25 working hours per week for up to 6 months. In addition, lump sums are provided under the Apprentice Scheme or Traineeship Scheme, but these measures apply only in England. Other measures taken to retain workers in the workplace and recover the economy include: miscellaneous benefits for businesses and the self-employed in the hospitality industry; Coronavirus Business Interruption Loan Scheme and Corona Large Business Interruption Loans Scheme as measures to facilitate access to and conditions for bank loans and credits; extension of deadlines and tax relief, etc. ${ }^{21}$

\subsection{Republic of Finland}

Finnish labor law is characterized by three specifics that influenced the approach of the Government of the Republic of Finland in creating measures to preserve jobs during the pandemic: 1 . Great emphasis is placed on the association of employers and workers in associations to the extent that almost all regulations related to labor law bring in the process of tripartite participation of the Government, employers and workers, noting that today over $70 \%$ of Finns belong to at least some form of workers' association. Thus, the workers themselves in Finland make payments to various funds of associations of their choice to provide funds for the payment of severance pay in the event of dismissal, unemployment benefits and other benefits in the field of social security. 2. The Law on Employment Contracts prescribes several mechanisms and obligations of employers so that the termination of the employment contract is really the ultima ratio. This is achieved primarily by the provisions of the law which impose on the employer the duty to try to find an adequate job for the employee in various ways or professionally improve him for another job before deciding to terminate the employment contract. Also, the institute of the so-called a lay-off which in special cases allows the employer

$21 \quad$ Ibid., pp. 542.-543. 
to declare temporary suspension of work and pay salaries, but that their other employment rights (length of service, right to annual leave, etc.) continue to run. Workers covered by such a measure may, at their option, receive unemployment benefits during that period or start working for another employer, which is terminated when the lay-off ceases. government agency established in 1937, primarily funded by the state (75\% in 2017), then health insurance payments (19\%) and payments of local territorial units (6\%), 81 with the aim of providing health and social insurance to residents, students and workers in Finland. It provides a variety of social and health benefits(benefits for parents with children under 17; benefits for single parents; benefits for kindergarten expenses, rent payments to students studying abroad and living in rented apartments, transportation fees; subsidized meals; treatment fees and rehabilitation, disability benefits, benefits in the event of the death of a family member, etc.) and serves as a backup source of benefits in the field of labor and social security for persons who are not members of trade unions or have already exercised their rights to benefits, unemployment benefits, pensions benefits for living and housing costs of pensioners). ${ }^{22}$

\section{STATE AID FOR ECONOMIC SUPPORT DURING THE COVIDA PANDEMIC 19}

\subsection{Legal framework for state aid in the context of the COVID pandemic 19}

Measures to help the economy as an economic and existential necessity are frequently discussed these days. The limitations offered by the existing legal framework for the granting of state aid to entrepreneurs have fallen into the background. However, the European Commission, as the "guardian of the Treaty" (now the TFEU) and the watchdog of the European Union's internal market, closely and systematically monitors developments and flexibly offers solutions and support to Member States in their intentions to preserve their economies. for the granting of permitted state aid. The following are some general remarks and several possible legal bases for granting state aid in this emergency situation. Considering financial support from EU or national public funds provided to health services or other public resolution services, COVID-19 does not fall under the state aid control regime. This also applies to any other financial support given directly to citizens. Namely, Member States can directly grant financial support to citizens, ie consumers, eg for canceled services, tickets or tickets that would not be reimbursed by the operator of such services. These measures also do not fall within the scope of State aid control and Member States may implement them immediately, without the involvement of the Commission. Under EU state aid rules, Member States can

$22 \quad$ Ibid., pp. 543.-544. 
devise abundant aid measures to support certain undertakings or sectors suffering from the effects of the COVID-19 epidemic in accordance with existing rules. In this respect, the following shall apply: 1. Member States may decide to take measures applicable to all undertakings, without discrimination. For example, wage subsidies or the suspension of corporate taxes and levies, value added taxes or social security contributions. Such measures alleviate the financial burden on companies in a direct and efficient way and do not contain a selective advantage for certain companies over others in comparable situations and therefore do not fall under the control of state aid and can be established immediately by Member States without the involvement of the European Commission. , that is, without her prior approval. Article 107 (3) TFEU provides that State aid rules allow Member States to adopt aid measures to meet acute liquidity needs and support victims facing possible bankruptcy due to the outbreak of the COVID-19 pandemic. Prior approval of the Commission is required as a condition for achieving this. It also provides for the right of Member States to grant emergency and temporary assistance in the form of loan guarantees or loans to all types of firms in difficulty. Such measures could cover the expected operational needs of the company for a period of 6 months. In addition, the possibility of assisting firms in difficulty and facing acute liquidity needs due to extraordinary and unforeseen circumstances such as the outbreak of COVID-19 is envisaged, taking into account relevant market conditions, especially given the level of the fee that the user is required to pay for a state guarantee or loan. Also, Member States could adopt state aid for small and medium-sized enterprises, which includes meeting their liquidity needs for a period of 18 months. ${ }^{23}$

\section{THE IMPACT OF THE COVID 19 PANDEMIC ON THE FISCAL SYSTEM AND TAXATION}

The impact of public policies on the COVID pandemic 19 in most countries of the world has had a direct and major impact on fiscal systems as such. Measures taken in all public policies to combat or reduce the pandemic are maintained on fiscal policy in all its segments, which is evident in the expenditure and revenue segments of the fiscal system since it affects the budgets, their revenue and expenditure sides. Of course, the fiscal response to the health and consequent and wider economic crisis shows the success or failure of public sector financial management. Crisis indicators also speak to the dramatic effects on public finances and the fiscal system as a whole. Namely, the fiscal system with its measures is at the

23 Law firm, Liszt \& Partners, Legal framework for state aid, related to the outbreak of the covid-19 pandemic, http://www.lipo.hr/docs/COVID_19\%20i\%20DR\%C5\%BDAVNE\%20POTPORE\%20-rev.pdf, Accessed, 29 June 2021 
same time an instrument for fighting the pandemic, but it is equally affected by it. Public revenues as such decreased by 15-30 percent in the first three months, and at the same time expenditures increased by some 30-40 percent, compared to the same period last year. Such a negative effect is exacerbated by growing deficits and growing public debt. Measures taken within all public policies are short-term and subject to constant adjustment, which is necessary given the relatively rapidly changing social, economic, social and fiscal environment and circumstances. At the same time, it is possible to monitor coordination in responding to the crisis at the international, European and even national level. The OECD and the European Union are preparing long-term measures and instruments, and at Union level, along with other instruments, a kind of temporary SURE framework has been offered. In this capacity, it is important to emphasize the types and manner of decision-making on all measures to combat the pandemic, as well as their fiscal system as a whole. Public finances will be adjusted through the change of classical but also adjusted instruments and through the creation of new instruments of fiscal policy to combat existing and possible future crises.

\subsection{Fiscal policy in response to the pandemic crisis}

Due to the great crisis that affected the whole world, the governments of a large number of member states were forced to take the necessary measures that were a kind of response to the pandemic, health and economic crisis. Although the differences vary both in scope and in the size of fiscal packages, they are all equally aimed at mitigating the direct impact of the sharp decline in economic activity on entrepreneurs, companies and households, and especially at preserving production capacity. Certainly, when considering challenges in the preparation and implementation of fiscal packages, fiscal policy measures specifically included the issue of criteria as well as the definition of necessity and necessity. What is especially important to note is the fact that countries apply a kind of lockdown, ie locking the entire economy and society, all in terms of a ban on work that is treated as an epidemiological measure in the fight against infection, which has a major impact on the fiscal system. undertake. Due to the above, it is important to single out social costs that confirm that these are unprecedented challenges. Namely, the crisis on the one hand leads to a sharp decline in fiscal revenues. In addition, a major fiscal effort is needed to preserve entrepreneurship while mitigating the growth of poverty and inequality as a pandemic crisis. ${ }^{24}$ Regarding the fiscal consequences in Croatia due to the response to the pandemic, it is important to emphasize that

24 Zunić-Kovačević Nataša, Consequences and effects of the COVID 19 pandemic on the fiscal system, Proceedings of the Faculty of Law in Split, Vol. 58., No. 2., 2021, pp. 485-486. 
in the extraordinary circumstances caused by the COVID pandemic, the Government of the Republic of Croatia has taken a number of measures to achieve economic goals. One of the main economic goals is to preserve or prevent a blow to the liquidity of the economy and entrepreneurs and households with the obligation to preserve jobs. When considering the effectiveness of these measures, it is necessary to distinguish between epidemiological measures adopted with the aim of preventing the infection, which are being introduced gradually and as such are becoming increasingly rigorous. The economy as such already requires a certain level of certainty and requires business people to make business decisions just as timely and quickly. Any government measure taken as a result of the crisis requires a reduction in government revenues while increasing the need for borrowing. Due to the above, the state is forced to give up some fiscal expenditures planned at a time when the crisis did not exist and could not have been foreseen. ${ }^{25}$ In addition to the above, it is interesting that the first case of COVID-19 in Croatia was confirmed in Zagreb, on February 25, 2020, by a young man who returned to the country from Italy. All this left great consequences on the entire fiscal system and at the same time led to the necessary changes in the tax system. On the other hand, the consequences in the fiscal system are especially visible through the reduction of all public revenues, both tax and non-tax. At the same time, there is a visible increase in public expenditures, ie public spending, primarily through the granted benefits, grants and aid, all with the announced tax relief. ${ }^{26}$

\section{EUROPEAN AND INTERNATIONAL COORDINATION IN RESPONSE TO THE PANDEMIC CRISIS AND RELATIONSHIP WITH NATIONAL FISCAL SYSTEMS}

On 20 March 2020, the European Commission adopted a Communication on the activation of the general clause derogating from the Stability and Growth Pact. The purpose of this clause is to weep over the coordination of the budgetary policies of the clauses at a time of severe economic downturn. In its Communication to the Council, the Commission stated that the current conditions allow the activation of this clause due to the expected serious economic downturn caused by the COVID-19 pandemic. Activation of the general derogation clause allows for a temporary deviation from the fiscal rules, provided that this does not jeopardize fiscal sustainability in the medium term. In the field of economy, a kind of investment initiative has been proposed in response to the coronavirus, which should allow flexible use of EU structural funds to respond to rapidly growing needs in

\footnotetext{
Ibid., p., 487.

Ibid., p., 488.
} 
the most exposed sectors. The most exposed sectors are health, small and mediumsized enterprises and labor markets, assistance to the most vulnerable areas such as health, SMEs and labor markets, and assistance to the most vulnerable areas in the Member States and their citizens. ${ }^{27}$

\section{GLOBAL HEALTH AND STATE INTEREST RELATED TO CORONAVIRUS}

As one of the last world crises, the coronavirus pandemic points to the circumstance of limiting international relations due to the protection of the population and the spread of the infection. In the following, we will try to present the complex character as well as the logic of the global spatial order in the field of health. The coronavirus has caused far-reaching political consequences for the coronavirus pandemic in terms of international political relations as well. In addition to slowing down global institutions with its work, it has also influenced the establishment of an insecure world as such. own power. International cooperation as such certainly exists and systematic work should be done to improve it, but cooperation between states is rather weak and the thesis is that "the state fears that others will either not adhere to their obligations or will benefit from cooperation." The "new reality" in which the power of the state is emphasized has introduced new measures to prevent the spread of the virus, starting with the closure of borders, quarantine, travel bans, etc. As a political issue, a pandemic requires the location of the state, its motives and interests in a broader context. The pandemic is primarily a political problem of global health management. In general, the notion of global governance is difficult to define as it refers to a space in which as such there is no hierarchy or established distribution of responsibilities. ${ }^{28}$

\subsection{Working from home in the age of the crown - advantages and disadvantages}

\section{Advantages}

Smart working, that is work from home, is a form of cooperation between workers and the work organization that has been constantly growing in the last few years. There is no doubt that there are many important positive benefits of working from home for a worker. A few will be listed below; greater privacy, productivity, motivation, flexibility at work or independence in determining working hours and breaks, saving time on the way to work and back and no stress on the way to

Ibid., pp. 490.-491.

28 Popović, Petar, Global Health and the Interest of the State, Annals of the Croatian Political Science Association: Journal of Political Science, Vol. 17., No. 1, 2020, pp.103-105, 
work, no nervous colleagues, flexible working hours, no high costs, such as the cost of petrol, a better balance between business and private life, more time for work as well as for ourselves, the possibility of going to the gym and nature during working hours.

\section{Disadvantages}

Regarding the shortcomings of working from home, it is important to point out inadequate sleep, a feeling of claustrophobia if the apartment is small, chaos in the house, disturbing other family members, more work, overtime unpaid. Also, one of the disadvantages is the frequent work on Saturdays and Sundays, which can significantly disrupt relations between household members. When a worker works in a small apartment, a full day stay in it can lead to a feeling of claustrophobia, a feeling of discomfort from the closed space, and when the worker is not alone at home and family members interfere with his work, this condition can cause nervousness, frustration, deconcentration. Furthermore, they are not a good condition for a worker, when the worker does not have a real desk and accompanying technology, when he does not have an ergonomic chair but sits on an ordinary chair or works from the bed, on the floor. When a worker has difficulty with self-discipline and difficulty concentrating which leads to him doing work tasks all day while feeling isolated. Poor communication with leaders and the entire team in these individuals further exacerbates his condition of isolation and leads to confusion. Staying in the house and being close to the refrigerator can lead to increased appetite and the use of food as an anti-stress which will lead to eating disorders. Workers from home can start from boredom eating less healthy food, sweets, baked and fried foods. On the other hand, people who live alone and do not leave the house all day can significantly reduce food intake. Prolonged working hours and late bedtime also lead to sleep disorders. ${ }^{29}$

\section{RECOMMENDATIONS FOR MAINTAINING MENTAL HEALTH IN THE AGE OF CORONAVIRUS}

Concern and anxiety about the corona virus and its impact can be a source of great stress for most people. Social distancing makes the whole situation even worse. Because of all this, it is important that we learn how to adequately deal with this pandemic and its impact on our entire lives. The coronary virus pandemic - COVID-19 has brought many changes in our lives, and thus uncertainty, a change in daily routine, fear for existence and social isolation. We take care of our health

29 Kostelić-Martic, Andreja, Coronavirus and mental health, Psychological aspects, advice and recommendations, Croatian Psychological Chamber, Zagreb, 2020, pp. 336.-339. 
every day, the length of the pandemic and ultimately what our future will be like. Information overload, various rumors and misinformation can lead us to a feeling of losing control in which we do not know what to do. It is normal these days to feel stress, anxiety, fear, sadness and loneliness. However, mental health disorders, including anxiety and depression, can get worse. Because of all this, it is important to learn how we can help ourselves so that we can cope with the everyday life that lies ahead. ${ }^{30}$

\section{CONCLUSION}

Coronavirus as a global, economic and health crisis suddenly caught us all and changed our private lives overnight, but also reorganized professional activities in such a way that in just a few days by mental health experts sought radical changes in established practices. In addition to the economy being exposed to multiple shocks, there is also a supply shock caused by supply chain disruptions, a demand shock caused by reduced consumer demand, a negative effect of uncertainty on investment plans and finally a limited liquidity effect on companies. It is important to emphasize that various restrictive measures have been adopted in order to shorten and limit the duration of the strike. This primarily refers to measures of social exclusion, travel restrictions, quarantine and confinement. It is important to emphasize that these measures are current in relation to supply and demand and affect companies and employees, especially in healthcare, tourism, culture, retail and transport. In addition to the direct consequences for mobility and trade, the COVIDA-19 pandemic is increasingly affecting mobility and trade, as well as companies in all sectors, small to medium and large. Namely, in extraordinary circumstances caused by a pandemic, companies of all kinds could find themselves in a situation of serious lack of liquidity. Solvent and somewhat less solvent firms could experience a sudden shortage or even unavailability of liquid assets. Small and medium-sized enterprises are particularly at risk. That is why in the short and medium term it could seriously affect the economic situation of many healthy companies and their employees, with long-term consequences for their survival. In addition, it is important to emphasize that banks and other financial intermediaries have a key role to play in mitigating the effects of the COVID 19 pandemic as they maintain the inflow of credit into the economy. If there is a serious restriction on the inflow of credit, economic activity will slow down sharply as companies will find it difficult to pay suppliers and employees. It is therefore appropriate that Member States may take measures to encourage credit institutions and other

30 Brezičević, Tamara, Mental health at the time of the corona virus pandemic (COVID-19), http://zzjzbpz.hr/images/stories/OVISNOSTI/2020/Mentalno-zdravlje-u-vrijeme-pandemije.pdf, Accessed 29 June 2021 
financial intermediaries to continue to play their role and to continue to support their activities in the Union. The question arises, how to prevent coronavirus. Here are some measures to prevent the spread of the infection in a systematic and effective way. The first and basic way is to wash your hands often and thoroughly with soap and water, avoid touching your eyes, mouth and nose with unwashed hands, avoid contact with people with symptoms of respiratory infections and avoid places where a lot of people gather. If you suspect an infection, you need to call a doctor or a territorially competent epidemiologist, do not go to the clinic and isolate yourself, and finally sneeze and cough into wipes or bent elbow in the absence of wipes. Of course, the basic guiding thought should be the patientphysician relationship, and the patient as such should always be in the first place, both his health and mental health.

\section{REFERENCES}

\section{BOOKS AND ARTICLES}

1. Akšamović, Dubravka, Legal Regime for Concentrations of Entrepreneurs in Competition Law, Collected Papers of the Faculty of Law, University of Rijeka, Vol. 29, No. 2., 2008.

2. Bilić, Andrijana, Mokrović, Domagoj, Preservation of jobs in times of crisis, Proceedings of the Faculty of Law in Split, Vol. 58, No. 2., 2021.

3. Kostelić-Martić, Andreja, Coronavirus and mental health, Psychological aspects, advice and recommendations, Croatian Psychological Chamber, Zagreb, 2020.

4. Kunda, Ivana, Law relevant for violations of competition law, Proceedings of the Faculty of Law, University of Rijeka, Vol. 39, No. 1., 2018.

5. Popović, Petar, Global Health and the Interest of the State, Annals of the Croatian Political Science Association: Journal of Political Science, Vol. 17., No. 1, 2020,

6. Zrno, Marija, How to make money on panic due to coronavirus; Protection of competition: How to avoid penalties in case of concentration of undertakings, Lider - business weekly, Vol. 16, No. 752., 2020.

7. Zunić - Kovačević, Nataša, Consequences and effects of the COVID 19 pandemic on the fiscal system and taxation, Collected papers of the law faculty in Split, Vol. 58., No. 2, 2021.

\section{LIST OF NATIONAL REGULATIONS, ACTS AND COURT DECISIONS}

1. Commission Communication, Fifth Amendment to the Temporary Framework for State Aid Measures to Support the Economy in the Current COVID-19 Pandemic and Amendment to the Communication to the Commission Communication to Member States on the Application of Articles 107 and 108 of the Treaty on the Functioning of the European Union to Short-Term Export Credit Insurance, 2021 / c, 34/06

2. Competition Act, (Official Gazette, No. 79/09, 80/13, 41/21) 


\section{WEBSITE REFERENCES}

1. Plechinger, Ivana, COVID-19 and entrepreneurs - how to take advantage of a bad situation for positive change; Entrepreneurship and COVID-19, https://www.radionica.hr/covid-19-ipoduzetnici/, Accessed 28 June 2021

2. Šimić, Vladimira, The latest coronavirus: how does COVID-19 affect the brain? https://www. adiva.hr/zdravlje/koronavirus/posljedice-koronavirusa-kako-covid-19-utjece-na-mozak/ Accessed 29 June 2021

3. Momčinović, Hrvoje, Concentration, http://www.aztn.hr/trzisno-natjecanje/nadleznosti/ koncentracije/ Accessed 29 June 2021

4. Barač, Ivana, Coronavirus is permanently changing the global labor market, https://privredni.hr/koronavirus-trajno-mijenja-globalno-trziste-rada, Accessed, 30 June 2021

5. Law firm, Liszt \& Partners, Legal framework for state aid, related to the outbreak of the covid 19-pandemic,http:/www.lipo.hr/docs/COVID_19\%20i\%20DR\%C5\%BDAVNE\%20 POTPORE\%20-rev.pdf, 29 June 2021

6. Brezičević, Tamara, Mental health at the time of the corona virus pandemic (COVID-19), http://zzjzbpz.hr/images/stories/OVISNOSTI/2020/Mentalno-zdravlje-u-vrijeme-pandemije.pdf, Accessed 29 June 2021 